Article

\title{
Effects of Exogenous Application of Osmotic Adjustment Substances on Growth, Pigment Concentration, and Physiological Parameters of Dracaena sanderiana Sander under Different Levels of Salinity
}

\author{
Pedro García-Caparrós ${ }^{1}$, Alfonso Llanderal ${ }^{1,2} \oplus$, Elodie Hegarat ${ }^{3}$, María Jiménez-Lao ${ }^{4}$ and \\ María Teresa Lao ${ }^{1, * \mathbb{D}}$ \\ 1 Agronomy Department of Superior School Engineering, University of Almeria, CIAIMBITAL, Agrifood \\ Campus of International Excellence ceiA3. Ctra. Sacramento s/n, La Cañada de San Urbano, 04120 Almería, \\ Spain; pedrogar123@hotmail.com (P.G.-C.); alfonsollanderal@hotmail.com (A.L.) \\ 2 Faculty of Technical Education for Development, Catholic University of Guayaquil, Av. C. J. Arosemena Km. \\ 1.5, Guayaquil 09014671, Ecuador \\ 3 Higher National School of Agronomy and Food Industries, Lorraine University, 54000 Nancy, France; \\ elodie.hegarat6@etu.univ-lorraine.fr \\ 4 Faculty of Biology Complutense, University of Madrid, 28040 Madrid, Spain; marinajl.al97@gmail.com \\ * Correspondence: mtlao@ual.es; Tel.: +34-950-015876; Fax: +34-950-015939
}

Received: 6 December 2019; Accepted: 10 January 2020; Published: 15 January 2020

\begin{abstract}
We evaluated two osmotic adjustment substances (glycine betaine (GB) and glycine (G) and a combination of both glycine + glycine betaine (G + GB) using two modes of application; irrigation and foliar sprays with Dracaena sanderiana plants. The plants were grown in containers and subjected to two levels of $\mathrm{NaCl}$ concentrations ( 2.0 and $7.5 \mathrm{dS} \mathrm{m}^{-1}$ ) over 8 weeks. Growth, pigment concentrations, and physiological parameters were assessed at the end of the trial. The foliar application of GB resulted in most optimal plant growth and biomass production in the presence of $\mathrm{NaCl}$. The chlorophyll and carotenoid concentrations showed different trends depending on the osmotic adjustment substance applied and the mode of application. Stomatal density and dimensions varied considerably with respect to the osmotic adjustment substance supplied. The concentration of soluble sugars in leaves did not show a clear trend under the different treatments assessed. The exogenous application of $\mathrm{G}$ resulted in the highest concentration of free proline and proteins in leaves. The antioxidant capacity in leaves increased with both osmotic adjustment substances, and both means of application, under low and high saline conditions. We concluded that the foliar application of GB can be recommended in order to achieve cost-effective growth of $D$. sanderiana under saline conditions.
\end{abstract}

Keywords: glycine; glycine betaine; proline; proteins; stomata size

\section{Introduction}

Salinity is an abiotic stress that causes sterile fields and reduces plant growth and yield [1] affecting an area of approximately 830 to 950 million hectares at a worldwide level [2]. Because of scarce irrigation and drainage practices, the degree of salinization in soils and groundwater is constantly increasing, especially in arid and semiarid areas in different parts of the world [3]. Salinization causes a reduction in the productivity of crops, valued at as much as US $\$ 12$ billion [4]. 
Plants grown in saline environments suffer osmotic stress and ion toxicity, which significantly reduce membrane porosity, growth rates, and yield [5]. The low rate of cell wall development and the reduction in growth are related to the osmotic stress caused by saline conditions in plants. The ionic stress comprises of a nutrient imbalance and a decrease in the photosynthetic apparatus in plants grown under saline environments [6].

Glycine betaine is a quaternary ammonium compound with a crucial role in osmotic maintenance in higher plants [7]. Glycine betaine can be taken up by plants at foliar and root level [8]. Foliar application of exogenous GB via seed or root soaking is considered to be a practical technique to improve plant resilience under stressed conditions and thus prolong, or improve, the yield of essential trading crops grown under both field and controlled environmental conditions [9]. For instance, the enhancement of salt tolerance through the external application of GB in different crops such as rice [10], melon [11], maize [12] wheat [13,14], eggplant [15], okra [16], as well as in ornamental species such as Viburnum lucidum L. and Callistemon citrinus (Curtis) Skeels [17], is well-known.

Amino acids such as $G$ are considered to be osmolytes, nitrogen sources, and hormone precursors [18]. The efficiency of foliar applications of amino acids under saline conditions has been investigated in many crops such as tomato [19], maize [20], and bean [21]. Reviewing previous literature concerning the benefits of the application of amino acid on plants shows that very little is known about the effects of the exogenous application of $G$ in plants. For instance, Badran et al. [22] assessed the consequences of $\mathrm{G}$ application on the homeostasis of wheat, reporting an increase of enzymatic and non-enzymatic antioxidants activity, and consequently a decrease in MDA and $\mathrm{H}_{2} \mathrm{O}_{2}$ levels. Yang et al. [23] investigated the positive effects of $\mathrm{G}$ application on lettuce, noting a significant increase in fresh weight and in the antioxidant activity.

The cultivation of ornamental plants in containers on the southeast coast of Spain has increased in recent years, mainly due to the high demand from consumers [24]. Nevertheless, water supplies in this region are scarce and they have high levels of salinity $[25,26]$, therefore an exhaustive study from an agronomic point of view concerning the ameliorative effects of variable osmolytes and the types of application in the production of ornamental species is necessary. We investigated Dracaena sanderiana Sander, a member of the family Agavaceae, known as "Lucky Bamboo". It is an evergreen shrubby plant, grown under indoor or outdoor conditions, highly demanded in the export market $[27,28]$. In the literature, very few studies have focused on the agronomic effects of the exogenous application of GB and $\mathrm{G}$ in ornamental plants. Therefore, the purpose of this experiment was to assess the effects of these chemical compounds: G, GB, and a combination of G + GB on growth, pigment concentration, and biochemical parameters in Dracaena sanderiana under different levels of salinity using two modes of application (irrigation and foliar sprays), in order to find out which osmotic adjustment substance and mode of application provides better salt tolerance in this species.

\section{Materials and Methods}

\subsection{Plant Material and Experimental Growing Conditions}

Initial single rooted cuttings of Dracaena sanderiana plants (leaf number: 10.3, height: $30.6 \mathrm{~cm}$, and total dry weight: $4.1 \mathrm{~g})$ were transplanted into containers $(1.5 \mathrm{~L})$ filled with a combination of sphagnum peat-moss and Perlite 80:20 (v/v) (Figure 1). The experiment was conducted over 8 weeks in a greenhouse belonging to University of Almeria $\left(36^{\circ} 49^{\prime} \mathrm{N}, 2^{\circ} 24^{\prime} \mathrm{W}\right)$. Records of climatic conditions during the trial were taken from HOBO SHUTTLE sensors (model H 08-004-02). The average temperature was $29.7 \pm 2.9^{\circ} \mathrm{C}$, relative humidity $(\mathrm{RH})$ was $59.2 \pm 1.6 \%$, and photosynthetically active radiation (PAR) was $290 \pm 12.4 \mu \mathrm{mol} \mathrm{m}^{-2} \mathrm{~s}^{-1}$. 


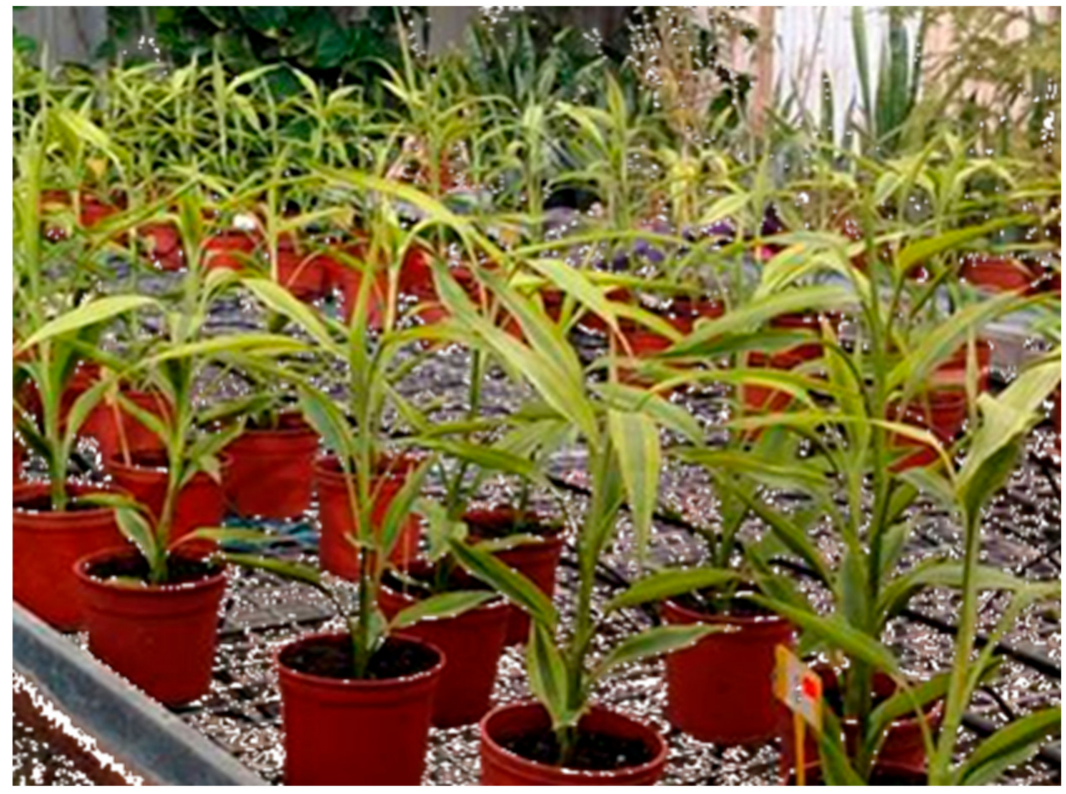

Figure 1. Front view of the experiment.

\subsection{Experimental Design and Treatments}

The experimental design consisted of a factorial combination split-plot-plot $(2 \times 2 \times 4)$, two salinity levels, two modes of application, and four osmotic adjustment substance treatments. Salinity levels were adjusted by the addition of $\mathrm{NaCl}$ to attain the electrical conductivity (EC) boundaries in the water for irrigation usually available to growers in this region: low EC, or control treatment, $\left(2.0 \mathrm{dS} \mathrm{m}^{-1}\right)$ $\left(\mathrm{S}_{1}\right)$, and high EC $\left(7.5 \mathrm{dS} \mathrm{m}^{-1}\right)\left(\mathrm{S}_{2}\right)$. All osmotic adjustment substances were applied in two ways-by irrigation $\left(\mathrm{F}_{1}\right)$, and by foliar spraying $\left(\mathrm{F}_{2}\right)$. The osmotic adjustment substances were: (1) distilled water (control) (C), (2) $25 \mathrm{mM} \mathrm{G}(\mathrm{G})$, (3) $25 \mathrm{mM} \mathrm{GB}$ (GB), and (4) $25 \mathrm{mM} \mathrm{G}+25 \mathrm{mM} \mathrm{GB}$ (G + GB).

Plants were irrigated with a standard nutrient solution composed of $0.70 \mathrm{H}_{2} \mathrm{PO}_{4}{ }^{-}, 6.00 \mathrm{NO}_{3}{ }^{-}$, $2.00 \mathrm{SO}_{4}{ }^{2-}, 3.00 \mathrm{~K}^{+}, 2.00 \mathrm{Ca}^{2+}$, and $1.40 \mathrm{Mg}^{2+}$ (expressed in $\mathrm{mmol} \mathrm{L}^{-1}$ ) and amended only with different concentrations of $\mathrm{NaCl}$ to achieve EC levels of irrigation water (ECi) of either 2.0 (low EC, $3 \mathrm{mmol} \mathrm{L}^{-1}$ $\mathrm{NaCl}$ ) or 7.5 (high EC $60 \mathrm{mmol} \mathrm{L}^{-1} \mathrm{NaCl}$ ) dS $\mathrm{m}^{-1}$. Daily plant irrigation was carried out manually $(60 \mathrm{~mL})$. The levels of salinity established in this experiment followed the recommendations given by García-Caparrós et al. [24,26]. Irrigation and foliar applications of G (99\% (w/v), Sigma-Aldrich, Darmstadt, Germany), GB (99\% (w/v), Sigma-Aldrich, Darmstadt, Germany), or the combination of both compounds $(G+G B)$, as well as the control (distilled water), were carried out weekly during the growing cycle. The concentration of osmotic adjustment substances used was in accord with the recommendations established by other researchers [29,30]. The experiment was laid out in a randomized complete-block design with four replicates per treatment. Each replicate was composed of four plants (one plant per pot) resulting in a total of 64 plants, plus adjacent plants.

\subsection{Color Parameters and Photosynthetic Pigment Concentration}

Plants were collected, and roots and leaves were cleaned with distilled water at the end of the experimental period ( 8 weeks) in order to remove G and GB residues added by foliar or irrigation application. The plants were divided into roots (R), stems (S), and leaves (L). These randomly-selected-per-treatment plants were used to determine color parameters and the concentration of photosynthetic pigments. The color index in the light and dark green area in leaf for red (R), green $(G)$, and blue (B) values was assessed using the procedure established by Kim et al. [31]. Briefly, the RGB values were determined using an optical scanner (ES-2000; Seiko Epson Corp., Suwa, Japan) and the pictures were analyzed with Adobe Photoshop CS6 (Adobe System Software, Dublin, Ireland) by averaging the $R, G$, and $B$ values (adimensional units) of all the leaf pixels. The same plants 
designated for the determination of leaf color index were also used to determine the concentrations of photosynthetic pigments in the different colored leaf areas. Extraction of chlorophyll a and b $(\mathrm{Chl} a$ and $\mathrm{Chl} b$ ) and carotenoids were performed by submerging $0.2 \mathrm{~g}$ of fresh leaves in methanol under darkness at room temperature $\left(15^{\circ} \mathrm{C}\right)$ for 1 day. The supernatant was removed, and the photosynthetic pigment concentrations were determined spectrophotometrically at their appropriate wavelengths Chl a $(\lambda=666 \mathrm{~nm}), \mathrm{Chl} \mathrm{b}(\lambda=653 \mathrm{~nm})$, and carotenoids $(\lambda=470 \mathrm{~nm})$ using a Shimadzu UV-1201 spectrophotometer (Shimadzu Scientific Instruments, Columbia, MD, USA), following the methodology of Wellburn [32].

\subsection{Biomass Parameters}

At the end of the harvesting, the same plants used to determine color parameters and photosynthetic pigments were used for measurements of growth parameters. Plant height was determined by measuring the distance from the top edge of the container to the last open leaf. The leaf number of each plant was counted directly. The longest root length was then determined, measuring the distance from the crown to the tip of the root. Total leaf area was determined prior to photosynthetic determinations from digitalized images of each plant using the Idrisi Selva computer program (Clark Laboratories, Worcester, MA, USA) as reported by García-Caparrós et al. [25]. The percentage of damage in the leaf area was calculated following the methodology established by Valdes et al. [33] in poinsettia plants grown under saline conditions. The variegation index was determined using the following equation (whole leaf area-green area)/(whole leaf area) according to the methodology proposed by Li et al. [34]. The different fractions of each plant (roots, stems, and leaves) were weighed to determine the fresh weight (FW). These fractions were then oven-dried at $60{ }^{\circ} \mathrm{C}$ for $48 \mathrm{~h}$ to determine the dry weight (DW). Total dry weight (TDW) was calculated as the sum of the different fractions of each plant (roots, stems, and leaves DW). The water content in plants (WC) (-) was calculated with the fresh and dry weight of the different fractions of plants using the following equation (FW-DW/DW) as indicated by Ben Amor et al. [35].

\subsection{Stomatal Density and Dimensions}

Stomatal features were analyzed at the end of the experimental period (Figure 2) using 10 leaves per treatment and 5 determinations per leaf. The leaf epidermis was removed by making a shallow cut on the lower surface of the leaf at a right angle to the veins using a razor-sharp blade following the methodology established by Rodriguez and Davies [36]. After fixation of the epidermis in distilled water, stomatal density (expressed as stomata number per $\mathrm{mm}^{2}$ ) and the length and width of stomata (expressed in $\mu \mathrm{m}$ ) were determined using an optical microscope (model Nikon Eclipse E800, Nikon Instruments, Amsterdam, The Netherlands) and a digital camera (model Jenoptik Speed Xt Core 5, Jenoptik, Jena, Germany). 


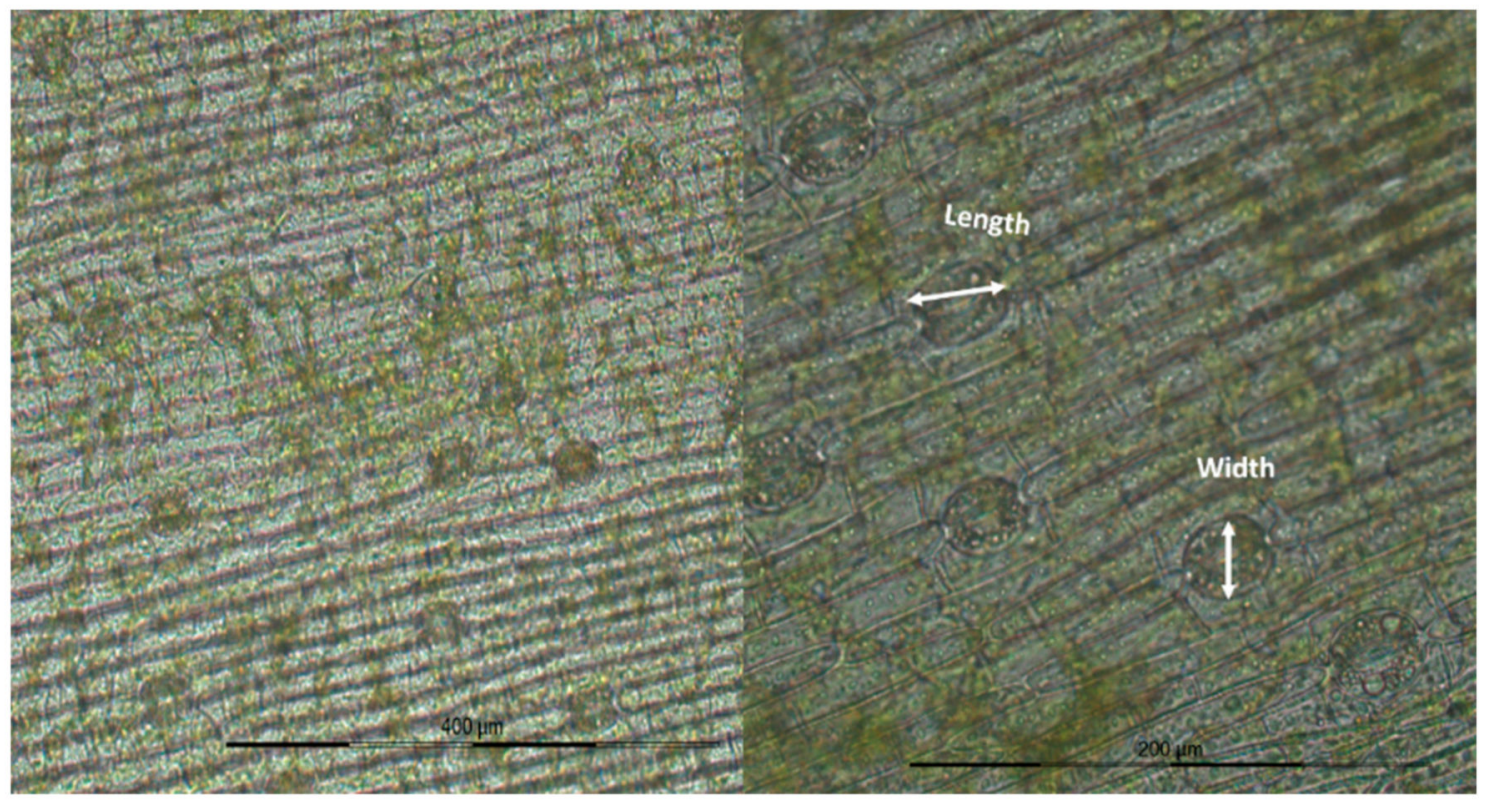

(a)

(b)

Figure 2. General view of the stomata determinations (a) and detailed view (b) (scale bar $=400 \mu \mathrm{m})$.

\subsection{Biochemical Parameters}

At the end of the harvesting, four plants were randomly selected per treatment to determine the following biochemical parameters in leaves (total soluble sugars (TSS), proline, and protein concentrations and antioxidant capacity). Fresh material ( $0.5 \mathrm{~g}$ of leaves) was crushed in $5 \mathrm{~mL}$ of $95 \%$ $\left(\mathrm{v} \mathrm{v}^{-1}\right)$ ethanol. Then, the pellet was washed with $5 \mathrm{~mL}$ of $70 \%\left(\mathrm{v} \mathrm{v}^{-1}\right)$ ethanol, being finally centrifuged (model Digicen $21 \mathrm{R}$ ) at $3500 \times \mathrm{g}$ for $10 \mathrm{~min}$. The free proline and total soluble sugars concentrations were determined in the alcoholic extract supernatant. Total soluble sugar concentrations (mg glucose $\left.\mathrm{g}^{-1} \mathrm{FW}\right)$ were assessed by the anthrone reagent method. Free proline concentration $\left(\mu \mathrm{g} \mathrm{g}^{-1} \mathrm{FW}\right)$ was assessed by the ninhydrin reagent method established by Irigoyen et al. [37]. Protein concentration $\left(\mathrm{mg} \mathrm{g}^{-1} \mathrm{FW}\right)$ was extracted with sodium phosphate buffer (50 mM, pH 7.0) and determined using the methodology reported by Bradford [38]. Total antioxidant capacity (\%) was assessed with the methodology established by Hatano et al. [39] using DPPH [2,2-diphenyl-1-picrylhydrazyl] under the extraction with methanol.

\subsection{Statistical Analysis}

The data presented in the tables are the means and standard deviation $(n=4)$. The data were subjected to three-way analysis of variance (ANOVA) and least significant difference (LSD) tests. The statistical analysis program used was Statgraphic Plus for Windows (version 5.1).

\section{Results}

\subsection{Plant Growth and Biomass Production}

Plant height declined under higher EC in the nutrient solution and showed the highest value under the application of GB, regardless of the mode of application (Table 1). Leaf number was not affected by either the levels of salinity or the mode of application, showing the highest values in plants treated with GB or G + GB. Root length increased under an increase in $\mathrm{NaCl}$ in the nutrient solution, and irrigation as the method of application resulted in the longest roots in plants treated with GB or G + GB. Total leaf area decreased under increasing $\mathrm{NaCl}$ concentrations, and irrigation as the method of application resulted in the lowest total leaf area in plants treated without the use of any osmotic adjustment substance. The percentages of damage in leaves increased under increasing 
$\mathrm{NaCl}$ concentrations using the irrigation method without the use of any osmotic adjustment substance. The variegation index was affected by none of the factors analyzed in the experiment, with values around 0.58. Total plant dry weight decreased under high EC in the nutrient solution, and plants to which GB was foliarly applied had the highest biomass production. Plant water content was only affected by the mode of application of the osmotic adjustment substances, and it was higher in irrigated plants.

\subsection{Color of Leaves}

In the light green area of the leaves, the red, green, and blue color decreased in plants grown under increasing $\mathrm{NaCl}$ concentrations to which the combination $\mathrm{G}+\mathrm{GB}$ was applied, regardless of the mode of application (Table 2).

In the dark green area of the leaves, the red, green, and blue color also decreased in plants grown under increasing $\mathrm{NaCl}$ concentrations with osmotic adjustment substances applied by irrigation. The lowest values were recorded in plants treated with the combination of G + GB.

\subsection{Photosynthetic Pigments}

In the light green area of the leaves, chlorophyll $a$ and $(a+b)$ concentrations increased in plants grown under increasing EC in the nutrient solution, and in those to which GB was applied foliarly had the highest concentration of photosynthetic pigments (Table 3). Chlorophyll b concentration decreased under increasing salinity, but remained unchanged regardless of the mode of application and the highest value was recorded in plants treated with G. Carotenoid concentration showed the highest value in plants under saline conditions, without application of osmotic adjustment substances and regardless of the mode of application.

In the dark green area of the leaves, chlorophyll $a$ and $(a+b)$ concentrations increased in plants grown under increasing EC and in those to which GB was applied foliarly. Chlorophyll b concentrations decreased under high EC conditions and irrigation as the method of application, and the highest value was recorded in plants where $G$ was applied. Carotenoid concentration showed the highest value in plants under saline conditions and irrigation as the method of application, without the use of any osmotic adjustment substance. 
Table 1. Effects of salinity level $\left(\mathrm{S}_{1}\right.$ : low electrical conductivity (EC) $\left(2 \mathrm{dS} \mathrm{m}^{-1}\right), \mathrm{S}_{2}$ : high EC $\left.\left(7.5 \mathrm{dS} \mathrm{m}^{-1}\right)\right)$, mode of application ( $\mathrm{F}_{1}$ : irrigation, $\mathrm{F}_{2}$ : foliar spray), and exogenous application of distilled water (control) (C), $25 \mathrm{mM}$ of glycine (G), $25 \mathrm{mM}$ of glycine betaine (GB), and $25 \mathrm{mM}$ of glycine plus $25 \mathrm{mM}$ of glycine betaine $(\mathrm{G}+\mathrm{GB})$ on growth parameters in potted Dracaena sanderiana plants grown in a greenhouse over 8 weeks.

\begin{tabular}{|c|c|c|c|c|c|c|c|c|}
\hline \multicolumn{9}{|c|}{ Growth Parameters } \\
\hline Factor & $\begin{array}{l}\text { Plant Height } \\
\text { (cm) }\end{array}$ & Leaf Number & $\begin{array}{l}\text { Root Length } \\
\text { (cm) }\end{array}$ & $\begin{array}{c}\text { Leaf Area } \\
\left(\mathrm{cm}^{2} \text { plant }^{-1}\right)\end{array}$ & \% Damages & $\begin{array}{l}\text { Variegation } \\
\text { Index }\end{array}$ & $\begin{array}{l}\text { Total Plant Dry } \\
\text { Weight (g) }\end{array}$ & $\begin{array}{c}\text { Plant Water } \\
\text { Content (-) }\end{array}$ \\
\hline A: Levels of Salinity & * & ns & * & * & * & ns & * & ns \\
\hline $\mathrm{S}_{1}$ & $35.39 \pm 1.02 \mathrm{a}$ & $15.62 \pm 0.48$ & $23.82 \pm 0.82 b$ & $382.42 \pm 8.02 \mathrm{a}$ & $1.57 \pm 0.02 \mathrm{~b}$ & $0.57 \pm 0.04$ & $7.83 \pm 0.20 \mathrm{a}$ & $3.88 \pm 0.15$ \\
\hline $\mathrm{S}_{2}$ & $32.39 \pm 0.99 b$ & $15.10 \pm 0.50$ & $27.90 \pm 0.90 \mathrm{a}$ & $364.91 \pm 8.41 \mathrm{~b}$ & $1.62 \pm 0.02 \mathrm{a}$ & $0.57 \pm 0.04$ & $7.24 \pm 0.18 b$ & $3.99 \pm 0.15$ \\
\hline B: Mode of Application & ns & ns & * & * & * & ns & * & * \\
\hline $\mathrm{F}_{1}$ & $33.46 \pm 0.88$ & $15.16 \pm 0.49$ & $26.54 \pm 0.94 \mathrm{a}$ & $368.64 \pm 8.02 b$ & $1.65 \pm 0.02 \mathrm{a}$ & $0.58 \pm 0.04$ & $7.17 \pm 0.19 b$ & $4.13 \pm 0.14 \mathrm{a}$ \\
\hline $\mathrm{F}_{2}$ & $34.89 \pm 0.92$ & $15.52 \pm 0.50$ & $24.18 \pm 0.80 \mathrm{~b}$ & $388.68 \pm 8.51 \mathrm{a}$ & $1.52 \pm 0.02 \mathrm{~b}$ & $0.58 \pm 0.04$ & $7.59 \pm 0.20 \mathrm{a}$ & $3.74 \pm 0.13 \mathrm{~b}$ \\
\hline C: Osmotic Adjustment Substances & * & * & * & * & * & ns & * & ns \\
\hline C & $34.33 \pm 1.02 \mathrm{~b}$ & $14.65 \pm 0.46 b$ & $24.31 \pm 0.79 b$ & $348.48 \pm 7.38 \mathrm{~d}$ & $1.86 \pm 0.03 \mathrm{a}$ & $0.58 \pm 0.04$ & $7.13 \pm 0.17 b$ & $4.01 \pm 0.14$ \\
\hline G & $31.17 \pm 0.91 c$ & $14.89 \pm 0.45 b$ & $24.06 \pm 0.76 b$ & $415.12 \pm 9.32 \mathrm{a}$ & $1.57 \pm 0.02 b$ & $0.57 \pm 0.03$ & $7.20 \pm 0.15 b$ & $3.93 \pm 0.13$ \\
\hline GB & $37.83 \pm 0.99 \mathrm{a}$ & $16.12 \pm 0.53 \mathrm{a}$ & $27.30 \pm 0.85 a$ & $396.09 \pm 8.67 b$ & $1.40 \pm 0.02 \mathrm{c}$ & $0.58 \pm 0.05$ & $8.39 \pm 0.22 \mathrm{a}$ & $3.86 \pm 0.15$ \\
\hline$G+G B$ & $33.38 \pm 0.90 \mathrm{bc}$ & $16.18 \pm 0.54 \mathrm{a}$ & $27.40 \pm 0.87 \mathrm{a}$ & $364.96 \pm 8.02 c$ & $1.55 \pm 0.02 \mathrm{~b}$ & $0.58 \pm 0.04$ & $7.10 \pm 0.15 \mathrm{~b}$ & $3.86 \pm 0.14$ \\
\hline \multirow[t]{4}{*}{ Interaction } & * & ns & $\mathrm{ns}$ & ns & ns & ns & ns & $\mathrm{ns}$ \\
\hline & * & ns & ns & ns & ns & ns & ns & ns \\
\hline & ns & ns & $\mathrm{ns}$ & ns & ns & ns & * & * \\
\hline & ns & ns & ns & ns & ns & ns & ns & ns \\
\hline
\end{tabular}

* indicates statistical differences. $n=4$. 
Table 2. Effects of salinity level $\left(\mathrm{S}_{1}\right.$ : low EC $\left(2 \mathrm{dS} \mathrm{m}^{-1}\right), \mathrm{S}_{2}$ : high EC $\left.\left(7.5 \mathrm{dS} \mathrm{m}^{-1}\right)\right)$, mode of application $\left(\mathrm{F}_{1}\right.$ : irrigation, $\mathrm{F}_{2}$ : foliar spray), and exogenous application of distilled water (control) (C), $25 \mathrm{mM}$ of glycine (G), $25 \mathrm{mM}$ of glycine betaine (GB), and $25 \mathrm{mM}$ of glycine plus $25 \mathrm{mM}$ of glycine betaine (G + GB) on leaf color in potted Dracaena sanderiana plants grown in a greenhouse over 8 weeks.

\begin{tabular}{|c|c|c|c|c|c|c|}
\hline \multicolumn{7}{|c|}{ Color of Leaves } \\
\hline Factor & \multicolumn{3}{|c|}{ Light Green Leaf Area } & \multicolumn{3}{|c|}{ Dark Green Leaf Area } \\
\hline & $\mathbf{R}$ & G & B & $\mathbf{R}$ & G & B \\
\hline A: Levels of Salinity & * & * & * & * & * & * \\
\hline $\mathrm{S}_{1}$ & $141.61 \pm 1.41 \mathrm{a}$ & $155.78 \pm 1.36 \mathrm{a}$ & $63.62 \pm 0.76 \mathrm{a}$ & $103.98 \pm 0.91 \mathrm{a}$ & $123.38 \pm 1.21 \mathrm{a}$ & $56.81 \pm 0.51 \mathrm{a}$ \\
\hline $\mathrm{S}_{2}$ & $138.49 \pm 1.30 \mathrm{~b}$ & $152.17 \pm 1.24 b$ & $59.98 \pm 0.53 b$ & $100.67 \pm 0.90 b$ & $120.25 \pm 1.17 \mathrm{~b}$ & $54.61 \pm 0.50 \mathrm{~b}$ \\
\hline B: Mode of Application & ns & ns & ns & * & $*$ & * \\
\hline $\mathrm{F}_{1}$ & $138.10 \pm 1.11$ & $155.97 \pm 1.31$ & $61.44 \pm 0.71$ & $101.24 \pm 0.91 b$ & $120.35 \pm 1.16 b$ & $55.31 \pm 0.55 b$ \\
\hline $\mathrm{F}_{2}$ & $139.20 \pm 1.17$ & $156.98 \pm 1.36$ & $62.16 \pm 0.68$ & $103.43 \pm 0.94 \mathrm{a}$ & $123.27 \pm 1.20 \mathrm{a}$ & $57.10 \pm 0.56 \mathrm{a}$ \\
\hline C: Osmotic Adjustment Substances & * & * & * & * & * & * \\
\hline C & $139.70 \pm 1.14 b$ & $154.27 \pm 1.22 \mathrm{c}$ & $63.99 \pm 0.77 b$ & $101.73 \pm 0.94 b$ & $121.30 \pm 1.13 b$ & $54.83 \pm 0.52 b$ \\
\hline G & $145.41 \pm 1.33 \mathrm{a}$ & $162.70 \pm 1.30 \mathrm{a}$ & $60.19 \pm 0.69 c$ & $105.34 \pm 0.99 \mathrm{a}$ & $123.21 \pm 1.20 \mathrm{a}$ & $54.99 \pm 0.51 \mathrm{~b}$ \\
\hline GB & $140.63 \pm 1.22 b$ & $158.39 \pm 1.19 \mathrm{~b}$ & $66.30 \pm 0.80 a$ & $102.00 \pm 0.95 b$ & $121.43 \pm 1.12 b$ & $57.36 \pm 0.57 \mathrm{a}$ \\
\hline $\mathrm{G}+\mathrm{GB}$ & $134.47 \pm 1.25 \mathrm{c}$ & $151.55 \pm 1.11 \mathrm{~d}$ & $54.73 \pm 0.56 \mathrm{~d}$ & $99.21 \pm 0.91 \mathrm{c}$ & $118.30 \pm 1.09 \mathrm{c}$ & $51.34 \pm 0.50 c$ \\
\hline \multirow[t]{4}{*}{ Interaction } & ns & ns & ns & ns & ns & ns \\
\hline & ns & * & ns & * & ns & ns \\
\hline & ns & ns & * & ns & ns & $*$ \\
\hline & ns & ns & ns & ns & ns & ns \\
\hline
\end{tabular}

Means with different letters within a column are significantly different at $p<0.05$ (analysis of variance and least significant difference test). Ns: indicates non-statistical differences. * indicates statistical differences. $n=4$. 
Table 3. Effects of salinity level $\left(\mathrm{S}_{1}\right.$ : low EC $\left(2 \mathrm{dS} \mathrm{m}^{-1}\right), \mathrm{S}_{2}$ : high EC $\left.\left(7.5 \mathrm{dS} \mathrm{m} \mathrm{m}^{-1}\right)\right)$, mode of application $\left(\mathrm{F}_{1}\right.$ : irrigation, $\mathrm{F}_{2}$ : foliar spray), and exogenous application of distilled water (control) (C), $25 \mathrm{mM}$ of glycine (G), $25 \mathrm{mM}$ of glycine betaine (GB), and $25 \mathrm{mM}$ of glycine plus $25 \mathrm{mM}$ of glycine betaine (G + GB) on photosynthetic pigments in the different leaf areas in potted Dracaena sanderiana plants grown in a greenhouse over 8 weeks.

\begin{tabular}{|c|c|c|c|c|c|c|c|c|}
\hline \multicolumn{9}{|c|}{ Photosynthetic Pigments ( $\left.\mathrm{mg} \mathrm{g}^{-1} \mathrm{FW}\right)$} \\
\hline \multirow[t]{2}{*}{ Factor } & \multicolumn{4}{|c|}{ Light Green Area } & \multicolumn{4}{|c|}{ Dark Green Area } \\
\hline & Chl a & Chl b & Chl $(a+b)$ & Carotenoids & Chl a & Chl b & Chl $(a+b)$ & Carotenoids \\
\hline A: Levels of Salinity & * & * & * & * & * & * & * & * \\
\hline $\mathrm{S}_{1}$ & $0.53 \pm 0.05 b$ & $0.20 \pm 0.02 \mathrm{a}$ & $0.70 \pm 0.05 \mathrm{~b}$ & $0.15 \pm 0.02 \mathrm{~b}$ & $0.91 \pm 0.06 \mathrm{~b}$ & $0.78 \pm 0.05 \mathrm{a}$ & $1.69 \pm 0.06 \mathrm{~b}$ & $0.07 \pm 0.01 \mathrm{~b}$ \\
\hline $\mathrm{S}_{2}$ & $0.69 \pm 0.06 \mathrm{a}$ & $0.11 \pm 0.01 \mathrm{~b}$ & $0.81 \pm 0.05 \mathrm{a}$ & $0.21 \pm 0.02 \mathrm{a}$ & $1.14 \pm 0.06 \mathrm{a}$ & $0.67 \pm 0.05 \mathrm{~b}$ & $1.82 \pm 0.06 \mathrm{a}$ & $0.15 \pm 0.02 \mathrm{a}$ \\
\hline B: Mode of Application & * & ns & * & ns & * & * & * & * \\
\hline $\mathrm{F}_{1}$ & $0.35 \pm 0.04 \mathrm{~b}$ & $0.16 \pm 0.02$ & $0.51 \pm 0.05 \mathrm{~b}$ & $0.18 \pm 0.02$ & $0.90 \pm 0.06 \mathrm{~b}$ & $0.64 \pm 0.05 \mathrm{~b}$ & $1.58 \pm 0.06 \mathrm{~b}$ & $0.09 \pm 0.01 \mathrm{~b}$ \\
\hline $\mathrm{F}_{2}$ & $0.57 \pm 0.05 \mathrm{a}$ & $0.15 \pm 0.02$ & $0.72 \pm 0.06 \mathrm{a}$ & $0.18 \pm 0.02$ & $1.07 \pm 0.06 \mathrm{a}$ & $0.75 \pm 0.05 \mathrm{a}$ & $1.77 \pm 0.07 \mathrm{a}$ & $0.13 \pm 0.02 \mathrm{a}$ \\
\hline C: Osmotic Adjustment Substances & * & * & * & * & * & * & * & * \\
\hline C & $0.69 \pm 0.05 b$ & $0.19 \pm 0.02 b$ & $0.83 \pm 0.07 \mathrm{~b}$ & $0.24 \pm 0.02 \mathrm{a}$ & $0.97 \pm 0.07 \mathrm{~b}$ & $0.64 \pm 0.04 c$ & $1.60 \pm 0.08 \mathrm{~b}$ & $0.13 \pm 0.01 \mathrm{a}$ \\
\hline G & $0.59 \pm 0.04 \mathrm{c}$ & $0.24 \pm 0.02 \mathrm{a}$ & $0.84 \pm 0.07 \mathrm{~b}$ & $0.13 \pm 0.01 \mathrm{~d}$ & $0.97 \pm 0.07 \mathrm{~b}$ & $0.83 \pm 0.05 a$ & $1.58 \pm 0.08 \mathrm{~b}$ & $0.05 \pm 0.01 \mathrm{c}$ \\
\hline GB & $0.81 \pm 0.06 \mathrm{a}$ & $0.18 \pm 0.02 b$ & $0.99 \pm 0.07 \mathrm{a}$ & $0.16 \pm 0.01 \mathrm{c}$ & $1.13 \pm 0.08 \mathrm{a}$ & $0.71 \pm 0.05 \mathrm{~b}$ & $1.80 \pm 0.08 \mathrm{a}$ & $0.09 \pm 0.01 \mathrm{~b}$ \\
\hline$G+G B$ & $0.42 \pm 0.04 \mathrm{~d}$ & $0.10 \pm 0.01 \mathrm{c}$ & $0.51 \pm 0.05 c$ & $0.19 \pm 0.01 \mathrm{~b}$ & $0.82 \pm 0.07 \mathrm{c}$ & $0.53 \pm 0.04 \mathrm{~d}$ & $1.36 \pm 0.07 \mathrm{c}$ & $0.08 \pm 0.01 \mathrm{~b}$ \\
\hline \multirow[t]{4}{*}{ Interaction } & ns & ns & ns & ns & $\mathrm{ns}$ & ns & ns & ns \\
\hline & ns & ns & ns & ns & ns & $\mathrm{ns}$ & ns & ns \\
\hline & ns & ns & ns & ns & $\mathrm{ns}$ & ns & ns & ns \\
\hline & ns & ns & ns & ns & ns & ns & ns & ns \\
\hline
\end{tabular}

Means with different letters within a column are significantly different at $p<0.05$ (analysis of variance and least significant difference test). Ns: indicates non-statistical differences. * indicates statistical differences. $n=4$. 


\subsection{Features of Stomata}

Stomatal density increased under higher EC in the nutrient solution, and it was highest in plants irrigated with GB. Stomata length showed the lowest value in plants treated with higher EC in the nutrient solution and foliar applications of GB (Table 4). The lowest values of width in stomata were also recorded in plants treated with GB regardless of the level of EC in the nutrient solution and the mode of application.

Table 4. Effects of salinity level $\left(\mathrm{S}_{1}\right.$ : low EC $\left(2 \mathrm{dS} \mathrm{m}^{-1}\right), \mathrm{S}_{2}$ : high EC $\left.\left(7.5 \mathrm{dS} \mathrm{m}^{-1}\right)\right)$, mode of application $\left(\mathrm{F}_{1}\right.$ : irrigation, $\mathrm{F}_{2}$ : foliar spray), and exogenous application of distilled water (control) $(\mathrm{C}), 25 \mathrm{mM}$ of glycine (G), $25 \mathrm{mM}$ of glycine betaine (GB), and $25 \mathrm{mM}$ of glycine plus $25 \mathrm{mM}$ of glycine betaine $(\mathrm{G}+\mathrm{GB})$ on stomatal parameters in potted Dracaena sanderiana plants grown in a greenhouse over 8 weeks.

\begin{tabular}{|c|c|c|c|}
\hline \multicolumn{4}{|c|}{ Stomatal Parameters } \\
\hline Factor & Stomatal Density (Stomata Number per $\mathrm{Mm}^{2}$ ) & Length $(\mu \mathrm{m})$ & Width $(\mu \mathrm{m})$ \\
\hline A: Levels of Salinity & * & * & ns \\
\hline $\mathrm{S}_{1}$ & $19.69 \pm 0.78 b$ & $31.94 \pm 0.23 \mathrm{a}$ & $27.32 \pm 0.20$ \\
\hline $\mathrm{S}_{2}$ & $21.42 \pm 0.81 \mathrm{a}$ & $31.41 \pm 0.21 b$ & $27.43 \pm 0.22$ \\
\hline B: Mode of Application & * & * & $\mathrm{ns}$ \\
\hline $\mathrm{F}_{1}$ & $21.44 \pm 0.77 \mathrm{a}$ & $31.43 \pm 0.20 \mathrm{~b}$ & $27.37 \pm 0.24$ \\
\hline $\mathrm{F}_{2}$ & $19.67 \pm 0.75 b$ & $31.92 \pm 0.21 \mathrm{a}$ & $27.39 \pm 0.24$ \\
\hline C: Osmotic Adjustment Substances & * & * & * \\
\hline $\mathrm{C}$ & $18.64 \pm 0.78 c$ & $31.87 \pm 0.23 b$ & $28.55 \pm 0.25 \mathrm{a}$ \\
\hline G & $20.40 \pm 0.76 b$ & $32.89 \pm 0.26 \mathrm{a}$ & $28.01 \pm 0.25 b$ \\
\hline GB & $22.72 \pm 0.80 a$ & $30.18 \pm 0.20 \mathrm{~d}$ & $26.29 \pm 0.22 \mathrm{~d}$ \\
\hline$G+G B$ & $20.46 \pm 0.79 b$ & $31.36 \pm 0.20 c$ & $26.96 \pm 0.23 c$ \\
\hline Interaction & ns & ns & ns \\
\hline $\mathrm{AC}$ & ns & ns & ns \\
\hline $\mathrm{BC}$ & ns & ns & ns \\
\hline $\mathrm{ABC}$ & ns & ns & ns \\
\hline
\end{tabular}

Means with different letters within a column are significantly different at $p<0.05$ (analysis of variance and least significant difference test). Ns: indicates non-statistical differences. ${ }^{*}$ indicates statistical differences. $n=4$.

\subsection{Biochemical Parameters}

The concentration of total soluble sugars in leaves declined under high EC in the nutrient solution, and it did not vary under the different modes of application. The highest concentration of total soluble sugars was found in plants to which osmotic adjustment substances were not applied at all (Table 5). The highest concentration of free proline was recorded in the leaves of plants treated with $G$ under high EC in the nutrient solution, regardless of the mode of application. The leaf antioxidant capacity decreased with increasing $\mathrm{NaCl}$ in the nutrient solution, and foliar application showed the lowest value in plants to which osmotic adjustment substances were not applied. The concentration of proteins was highest in the leaves of plants treated with lower EC in the nutrient solution and to which G was applied foliarly. 
Table 5. Effects of salinity level $\left(\mathrm{S}_{1}\right.$ : low EC $\left(2 \mathrm{dS} \mathrm{m}^{-1}\right), \mathrm{S}_{2}$ : high EC $\left.\left(7.5 \mathrm{dS} \mathrm{m}^{-1}\right)\right)$, mode of application $\left(\mathrm{F}_{1}\right.$ : irrigation, $\mathrm{F}_{2}$ : foliar spray), and exogenous application of distilled water (control) (C), $25 \mathrm{mM}$ of glycine (G), $25 \mathrm{mM}$ of glycine betaine (GB), and $25 \mathrm{mM}$ of glycine plus $25 \mathrm{mM}$ of glycine betaine $(G+G B)$ on biochemical parameters in potted Dracaena sanderiana plants grown in a greenhouse over 8 weeks.

\begin{tabular}{|c|c|c|c|c|}
\hline \multicolumn{5}{|c|}{ Biochemical Parameters } \\
\hline Factor & $\begin{array}{c}\text { TSS } \\
\left(\mu \mathrm{g} \mathrm{g}^{-1} \text { FW) }\right.\end{array}$ & $\begin{array}{c}\text { Proline } \\
\left(\mu \mathrm{g} \mathrm{g}^{-1} \mathrm{FW}\right)\end{array}$ & $\begin{array}{l}\text { Antioxidant } \\
\text { Capacity (\%) }\end{array}$ & $\begin{array}{c}\text { Proteins } \\
\left(\mathrm{mg} \mathrm{g}^{-1} \mathrm{FW}\right)\end{array}$ \\
\hline A: Levels of Salinity & * & * & * & * \\
\hline $\mathrm{S}_{1}$ & $39.58 \pm 1.51 \mathrm{a}$ & $6.95 \pm 0.03 b$ & $89.63 \pm 3.72 \mathrm{a}$ & $38.10 \pm 1.75 a$ \\
\hline $\mathrm{S}_{2}$ & $36.38 \pm 1.43 b$ & $7.04 \pm 0.03 \mathrm{a}$ & $81.19 \pm 3.43 b$ & $32.33 \pm 1.61 \mathrm{~b}$ \\
\hline B: Mode of Application & ns & ns & * & * \\
\hline $\mathrm{F}_{1}$ & $39.69 \pm 1.48$ & $6.97 \pm 0.03$ & $89.08 \pm 3.61 \mathrm{a}$ & $31.64 \pm 1.47 \mathrm{~b}$ \\
\hline $\mathrm{F}_{2}$ & $38.26 \pm 1.44$ & $6.98 \pm 0.03$ & $81.74 \pm 3.40 \mathrm{~b}$ & $38.79 \pm 1.55 \mathrm{a}$ \\
\hline C: Osmotic Adjustment Substances & * & * & * & * \\
\hline $\mathrm{C}$ & $42.04 \pm 1.88 \mathrm{a}$ & $6.93 \pm 0.03 b$ & $76.67 \pm 3.23 c$ & $41.28 \pm 1.61 \mathrm{~b}$ \\
\hline G & $36.83 \pm 1.40 \mathrm{~b}$ & $7.02 \pm 0.04 \mathrm{a}$ & $84.22 \pm 3.58 b$ & $46.03 \pm 1.65 \mathrm{a}$ \\
\hline GB & $37.29 \pm 1.38 \mathrm{~b}$ & $6.94 \pm 0.03 b$ & $83.82 \pm 3.61 \mathrm{~b}$ & $31.05 \pm 1.35 c$ \\
\hline$G+G B$ & $36.73 \pm 1.35 b$ & $6.91 \pm 0.03 b$ & $97.49 \pm 4.02 \mathrm{a}$ & $24.49 \pm 1.22 \mathrm{~d}$ \\
\hline \multirow{4}{*}{ Interaction } & ns & ns & ns & ns \\
\hline & * & ns & ns & ns \\
\hline & ns & ns & ns & ns \\
\hline & ns & ns & ns & ns \\
\hline
\end{tabular}

Means with different letters within a column are significantly different at $p<0.05$ (analysis of variance and least significant. difference test). Ns: indicates non-statistical differences. ${ }^{*}$ indicates statistical differences. $n=4$.

\section{Discussion}

In our experiment, plant height got shorter by high salt. Nevertheless, GB cancelled this negative effect by high salt. Similar results were reported by other researchers, for instance, Rahman et al. [10] noted that GB application reduced damage in rice plants grown under saline conditions, resulting in a slight increase in the height of the plants. Similarly, Osman and Salim [40] reported that the foliar application of GB $(25 \mathrm{mM})$ resulted in an increase in the height of snap beans under salinity. The increase in plant height may be ascribed to the amelioration of salt damages in photosynthesis due to the exogenous application of GB, and consequently the positive effects of this osmotic adjustment substance may result in a higher synthesis of photosynthetic assimilates that are translocated to actively growing and expanding parts of plants promoting the growth.

Leaf number was not affected either by different levels of salinity or by the mode of application of the osmotic adjustment substances, but it was highest in plants treated with GB, or the combination of G + GB. An increase in leaf number under GB application has also been reported in horticultural crops such as lettuce [41], and ornamental plants such as Viburnum lucidum [17]. The increase in leaf number in plants treated with GB may be explained as it was previously commented in plant height.

Root length of $D$. sanderiana increased under high salinity level and irrigation application being also promoted with the application of GB, or the combination of G + GB. The increase in root length under saline conditions in this species is a feature which is also triggered in some other ornamental plants [42]. Different results were reported by Habib et al. [16], where okra plants showed a significant decrease in root length due to root zone salinity, although the foliar spraying of GB led to an increase in root length in this ornamental plant. The increase in root length in plants treated with GB in our experiment may contribute to a better capacity of nutrient uptake and consequently a greater height and number of leaves, as previously mentioned.

Saline conditions may cause a change in leaf area in ornamental species [43]. Our results showed that under high EC of the nutrient solution there was a reduction in the leaf area. Nevertheless, $\mathrm{G}$ and GB ameliorated this effect especially under foliar application. Similar results were reported by Cirillo et al. [17] in Callistemon citrinus, where the increase in $\mathrm{NaCl}$ from $1 \mathrm{mM}$ to $200 \mathrm{mM}$ in the nutrient solution resulted in a decrease in leaf area. Nevertheless, in this experiment, irrigation with 
GB did not show any differences compared to the control treatment sprayed only with distilled water, whereas in our experiment the exogenous application of GB resulted in an increase in leaf area.

The percentage of damage to leaves increased under high salinity. All the osmotic adjustment substances reduced the percentage of damages compared to the control treatment, especially under foliar application. From these results, we hypothesized that foliar GB application may reduce the translocation of toxic ions such as $\mathrm{Na}$ and $\mathrm{Cl}$ from the root to the shoot region, as suggested by Sobahan et al. [44]. Similar findings were reported by Rahman et al. [10] in salt stressed rice seedlings where irrigation by GB mitigated leaf damage caused by salinity. No applications of osmotic adjustment substances led to a higher percentage of damage in plants and consequently to a significant reduction in leaf area, as happened in our experiment.

Regarding the data acquired in our experiment, it can be highlighted that the variegation index was not affected by any of the factors assessed in this experiment. Other experiments have reported that changes in the variegation index can be related to changing light conditions, although the response tends to be species specific [45]. Foliage crops, including Epipremnum aureum Lindl [46] and Hedera helix L. [47], were more variegated under high light intensity, whereas Dracaena sanderiana and Peperomia obtusifolia L. A. Dietr both shade obligate species, were more variegated when grown under low light $[45,48]$.

In this experiment, the growth of this species under high saline conditions reduced the total plant dry weight. Nevertheless, under the foliar application of GB, the total dry weight of $D$. sanderiana was ameliorated. The increase in total plant dry weight in this species can be ascribed to the increase in leaf number and plant height, as already mentioned. The reduction in growth and yield is a well-known consequence of the growth of plants under salt stressed conditions [49]. These inhibitory effects may be related to the induced osmotic stress and the toxic effects of the accumulation of ions such as $\mathrm{Na}^{+}$and $\mathrm{Cl}^{-}$, along with reduced photosynthesis due to the salt stress conditions, as indicated by Athar et al. [50]. The enhancement of total plant dry weight under foliar GB application was in line with the results obtained by other researchers with different crops, such as tomato [51], canola [52], eggplant [15], and okra [16], where foliar GB treatments alleviated salt damage in these species.

In our experiment, plant water content only varied due to the mode of application of the osmotic adjustment substances, being higher in irrigated plants. Similar results were reported by Yang et al. [53], who noted no significant differences in water content in two perennial grass species irrigated with different osmolytes under saline conditions. Conversely, other researchers have reported that the exogenous application of GB improved water potential under salt stress in crops such as maize [12], which can be related to the enhancement of the water flow from roots to shoots by increasing the hydraulic conductivity, as suggested by Hu et al. [29].

As far as color parameters were concerned, there were similar patterns in both areas (light and dark green) assessed in leaves, since $R, G$, and B values showed the lowest values in plants grown under increasing saline conditions. The decrease of $R$ and $G$ values were improved under the application of glycine and the value of $B$ under the application of GB. In addition, in the dark green leaf area, the mode of application of the osmotic adjustment substances had an effect on color parameters. To the best of our knowledge, there are no literature data concerning the effects of the application of osmotic adjustment substances on RGB values in crops, but there are studies in which RGB imaging have been assessed to assay salinity tolerance $[54,55]$. Our results suggest that the decrease of RGB values in plants treated with the combination of G and GB may be related to the decrease in the chlorophyll concentration in those leaves, and the highest value of $\mathrm{B}$ can be ascribed to the increase in the chlorophyll concentration.

Regarding pigment concentration, under saline conditions there is an increase of chlorophyll a, $(\mathrm{a}+$ b) and carotenoids concentration and a decrease in chlorophyll b in both areas studied. The application of GB improved the concentration of chlorophyll a, especially under foliar application, and the application of $\mathrm{G}$ increased the concentration of chlorophyll $b$. These results may suggest a strong relationship between pigment concentration and photosynthetic efficiency, which results in a greater number of leaves and, hence, in total plant dry weight. According to the literature, the application of 
GB results in an increase in pigment concentration compared to control plants (to which no osmotic adjustment substances have been applied) [56]. Nevertheless, it is necessary to point out that the growth of species under saline conditions had a species-specific response concerning pigment concentration, since several studies reported a decrease under saline conditions [22,57] mainly related to membrane deterioration in chloroplast [58], whereas others reported an increase $[59,60]$ which can be attributed to an increase in the number of chloroplast per unit leaf area, as reported by Chaum and Kirdmanee [61].

With respect to the stomata parameters evaluated in this experiment, it can be highlighted that under saline conditions there was an increase in stomatal density and a decrease in length. Moreover, the application of GB also increased stomatal density but showed a small size (length and width). Nevertheless, G promoted length stomata. The higher stomatal density in plants treated with GB may result in a higher gas exchange and consequently in a higher rate of growth, as occurred in our experiment. In the same vein, the changes in stomatal size and density may be attributed to changes in the size of epidermal cells, resulting in a total smaller area and higher stomatal density, as suggested by Maksimovic et al. [62]. The stomatal narrowing in plants treated with GB can be related to the reduction of water loss during abiotic stress like salinity, as occurred in our experiment.

Biosynthesis and accumulation of osmolytes (compatible with the cell metabolism) is essential for the maintenance of osmotic conditions in plants grown under saline conditions [63]. In our experiment, the concentration of total soluble sugars in leaves was higher in plants under low EC in the nutrient solution, without the application of any osmotic adjustment substance. In our experiment, the concentration of total soluble sugars in leaves decreased under saline conditions and the application of the different osmotic adjustment substances did not increase the concentration of total soluble sugars in leaves. Conversely, other researchers have reported that under saline conditions and foliar application of GB, there was an increase in total soluble sugars in leaves in other crops, such as lettuce and cowpea [57,60]. Likewise, Badran et al. [22] reported an increase of leaf total soluble sugars under $\mathrm{G}$ application in wheat grown under increasing saline conditions.

In our experiment, the concentration of free proline in leaves increased under saline conditions. On the same hand, the application of $G$, regardless of the mode of application, increased leaf proline concentration. These results may suggest that proline could be an adequate osmolyte in this ornamental crop under saline conditions. However, other studies show that there are different and variable results. For instance, an increase in leaf proline concentration has also been reported in response to salt stress and the application of GB compared to control treatments in different crops, such as pepper and soybean $[30,64]$. These results of increasing proline concentration can be ascribed to the defensive function of GB on some crucial enzymes responsible for the biosynthesis of free proline [65]. There are also reports which noted an increase in proline concentration under salt stressed conditions, but the application of GB led to a decline in proline concentration, for example in perennial ryegrass [29]. These results of decreased proline concentration may be ascribed to the participation of GB in the process of osmotic adjustment, instead of proline accumulation as suggested by Demiral and Turkan [66].

In our experiment, there was a decrease in the antioxidant capacity under high salinity. Nevertheless, G + GB increased the antioxidant capacity, especially under irrigation application. The decrease in the antioxidant capacity in leaves under high EC in the nutrient solution and irrigation, showing the highest value in plants treated without any osmotic adjustment substances, can be associated with the high percentages of damage to leaves reported in plants under the same treatment. The results of our experiment were not in line with the results reported by Mohammed and Tarpley [67], who noted no variations in the antioxidant capacity in leaves of rice under different doses of GB applied through foliar sprays. No variations in antioxidant capacity compared to our experiment could be to the high concentration of GB $(580 \mathrm{mM})$ applied by these researchers.

In our experiment, the concentration of proteins declined under high salinity level. Nevertheless, $G$ increased the leaf protein concentration, especially under foliar application. However, previous studies show different and variable results. Habib et al. [16] reported a decline in leaf protein concentration in okra under saline conditions, but the foliar application of $10 \mathrm{mM} \mathrm{GB}$ increased the 
protein concentration in these plants, whereas Osman and Salim [40] reported no variations in protein concentration under saline conditions and foliar application of GB in snap beans. Considering that GB plays an important role in proteins protection, the results of this experiment may suggest that the concentration of osmotic adjustment substances applied in this species was not enough to maintain this role.

\section{Conclusions}

The present experiment demonstrated that the exogenous application of osmotic adjustment substances such as GB and G can result in an improvement in the growth of $D$. sanderiana, where treatment with GB proved to be the most efficient.

Pigment concentrations showed different trends depending on the osmotic adjustment substance applied and the mode of application. Stomatal density and dimensions varied considerably with respect to the osmotic adjustment substance supplied, showing a high stomatal density and consequently reduced length and width in plants treated with GB. The concentration of soluble sugars in leaves did not show a clear trend under the treatments assessed. The application of $G$ resulted in the highest concentration of free proline and proteins in leaves. With respect to the antioxidant capacity in leaves, there was an increase under both osmotic adjustment substances, and both means of application, under low and high saline conditions.

Future research should be focused on the understanding of how these osmotic adjustment substances can affect the nutritional parameters, hormone biosynthesis, and antioxidant metabolism. In this way, it will be possible to achieve a better understanding of the role of $G$ and GB as osmotic adjustment substances in $D$. sanderiana plants under saline conditions.

Author Contributions: P.G.-C. investigation, data curation, writing-original draft preparation. A.L. formal analysis, investigation. E.H. formal analysis, investigation. M.J.-L. formal analysis, investigation. M.T.L. conceptualization, supervision, project administration. All authors have read and agreed to the published version of the manuscript.

Funding: This research received no external funding.

Acknowledgments: The authors thank I. Maksimovic for her suggestions and English style corrections. The authors also thank the funding of this work by the group AGR-242 from University of Almería (Sustainability of Horticultural and Ornamental Protected Systems).

Conflicts of Interest: The authors declare no conflict of interest.

\section{References}

1. Deinlein, U.; Stephan, A.B.; Horie, T.; Luo, W.; Xu, G.; Schroeder, J.I. Plant salt-tolerance mechanisms. Trends Plant Sci. 2014, 19, 371-379. [CrossRef] [PubMed]

2. Flowers, T.J.; Colmer, T.D. Plant salt tolerance: Adaptations in halophytes. Ann. Bot. 2015, 115, $327-331$. [CrossRef] [PubMed]

3. Cassaniti, C.; Romano, D.; Hop, M.E.C.M.; Flowers, T.J. Growing floricultural crops with brackish water. Environ. Exp. Bot. 2013, 92, 165-175. [CrossRef]

4. Qadir, M.; Quillérou, E.; Nangia, V.; Murtaza, G.; Singh, M.; Thomas, R.J.; Drechsel, P.; Noble, A.D. Economics of salt-induced land degradation and restoration. Nat. Res. Forum 2014, 38, 282-295. [CrossRef]

5. Tuteja, N.; Peter Singh, L.; Gill, S.S.; Gill, R.; Tuteja, R. Salinity stress: A major constraint in crop production. In Improving Crop Resistance to Abiotic Stress; Wiley-VCH Verlag GmbH \& Co. KGaA: Weinheim, Germany, 2012; pp. 71-96.

6. Munns, R.; Gilliham, M. Salinity tolerance of crops-What is the cost? New Phytol. 2015, 208, 668-673. [CrossRef]

7. Ashraf, M.; Foolad, M. Roles of glycine betaine and proline in improving plant abiotic stress resistance. Environ. Exp. Bot. 2007, 59, 206-216. [CrossRef]

8. Chen, T.H.H.; Murata, N. Glycinebetaine: An effective protectant against abiotic stress in plants. Trends Plant Sci. 2008, 13, 499-504. [CrossRef] 
9. Kurepin, L.V.; Ivanov, A.G.; Zaman, M.; Pharis, R.P.; Hurry, V.; Hüner, N.P. Interaction of glycine betaine and plant hormones: Protection of the photosynthetic apparatus during abiotic stress. In Photosynthesis: Structures, Mechanisms, and Applications; Springer: Cham, Switzerland, 2017; pp. 185-202.

10. Rahman, M.S.; Miyake, H.; Takeoka, Y. Effects of exogenous glycinebetaine on growth and ultra-structure of salt-stressed rice seedlings (Oryza sativa L.). Plant Prod. Sci. 2011, 5, 33-44. [CrossRef]

11. Kaya, C.; Tuna, A.L.; Ashraf, M.; Altunlu, H. Improved salt tolerance of melon (Cucumis melo L.) by the addition of proline and potassium nitrate. Environ. Exp. Bot. 2007, 60, 397-403. [CrossRef]

12. Nawaz, K.; Ashraf, M. Improvement in salt tolerance of maize by exogenous application of glycinebetaine: Growth and water relations. Pak. J. Bot. 2007, 39, 1647-1653.

13. Raza, S.H.; Athar, H.; Ashraf, M.; Hameed, A. Glycinebetaine induced modulation of antioxidant enzymes activities and ion accumulation in two wheat cultivars differing in salt tolerance. Environ. Exp. Bot. 2007,60, 368-376. [CrossRef]

14. Mahmood, T.; Ashraf, M.; Shahbaz, M. Does exogenous application of glycinebetaine as a pre-sowing seed treatment improve growth and regulate some key physiological attributes in wheat plants grown under water deficit conditions? Pak. J. Bot. 2009, 41, 1291-1302.

15. Abbas, W.; Ashraf, M.; Akrama, N.A. Alleviation of salt-induced adverse effects in eggplant (Solanum melongena L.) by glycinebetaine and sugarbeet extracts. Sci. Hortic. 2010, 125, 188-195. [CrossRef]

16. Habib, N.; Ashraf, M.; Ali, Q.; Perveen, R. Response of salt stressed okra (Abelmoschus esculentus Moench) plants to foliar-applied glycine betaine and glycine betaine containing sugar beet extract. S. Afr. J. Bot. 2012, 83, 151-158. [CrossRef]

17. Cirillo, C.; Rouphael, Y.; Caputo, R.; Raimondi, G.; Sifola, M.I.; De Pascale, S. Effects of high salinity and the exogenous application of an osmolyte on growth, photosynthesis, and mineral composition in two ornamental shrubs. J. Hort. Sci. Biotech. 2016, 91, 14-22. [CrossRef]

18. Maeda, H.; Dudareva, N. The shikimate pathway and aromatic amino acids biosynthesis in plants. Annu. Rev. Plant Biol. 2012, 63, 73-105. [CrossRef]

19. Tantawy, A.S.; Abdel-Mawgoud, A.M.R.; El-Nemr, M.A.; Chamoun, Y.G. Alleviation of salinity effects on tomato plants by application of amino acids and growth regulators. Eur. J. Sci. Res. 2009, 30, 484-494.

20. El-Samad,H.M.; Shaddad, M.A.K.; Barakat, N. Improvement of plants salt tolerance by exogenous application of amino acids. J. Med. Plants Res. 2011, 5, 5692-5699.

21. Sadak, M.; Abdelhamid, M.T.; Schmidhalter, U. Effect of foliar application of aminoacids on plant yield and some physiological parameters in bean plants irrigated with seawater. Acta Biol. Colomb. 2015, 20, 141-152.

22. Badran, E.G.; Abogadallah, G.M.; Nada, R.M.; Alla, M.M.N. Role of glycine in improving the ionic and ROS homeostasis during $\mathrm{NaCl}$ stress in wheat. Protoplasma 2015, 252, 835-844. [CrossRef]

23. Yang, X.; Cui, X.; Zhao, L.; Guo, D.; Feng, L.; Wei, S.; Zhao, C.; Huang, D. Exogenous glycine nitrogen enhances accumulation of glycosylated flavonoids and antioxidant activity in lettuce (Lactuca sativa L.). Front. Plant Sci. 2017, 8, 2098. [CrossRef] [PubMed]

24. García-Caparrós, P.; Llanderal, A.; Pestana, M.; Correia, P.J.; Lao, M.T. Tolerance mechanisms of three potted ornamental plants grown under moderate salinity. Sci. Hortic. 2016, 201, 84-91. [CrossRef]

25. García-Caparrós, P.; Llanderal, A.; El-Tarawy, A.; Majsztrik, J.; Lao, M.T. Response of container-grown Confeti tree irrigated with runoff water. HortTechnology 2017, 27, 625-630. [CrossRef]

26. García-Caparrós, P.; Contreras, J.I.; Baeza, R.; Segura, M.L.; Lao, M.T. Integral management of irrigation water in intensive horticultural systems of Almeria. Sustainability 2017, 9, 2271. [CrossRef]

27. Aslam, J.; Mujib, A.; Sharma, M.P. In vitro micropropagation of Dracaena sanderiana Sander ex Mast: An important indoor ornamental plant. Saudi J. Biol. Sci. 2013, 20, 63-68. [CrossRef]

28. Sereshti, H.; Eskandarpour, N.; Samadi, S.; Aliakbarzadeh, G. Investigation on Dracaena sanderiana phytoremediation ability for $\mathrm{Hg}$ and $\mathrm{Cd}$ using multivariate optimized task specific ionic liquid-based dispersive liquid-liquid microextraction. Int. J. Environ. Res. 2014, 8, 1075-1084.

29. Hu, L.; Hu, T.; Zhang, X.; Pang, H.; Fu, J. Exogenous glycine betaine ameliorates the adverse effect of salt stress on perennial ryegrass. J. Am. Soc. Hortic. Sci. 2012, 137, 38-46. [CrossRef]

30. Malekzadeh, P. Influence of exogenous application of glycinebetaine on antioxidative system and growth of salt-stressed soybean seedlings (Glycine max L.). Physiol. Mol. Biol. Plants 2015, 21, 225-232. [CrossRef]

31. Kim, J.; Kang, S.W.; Pak, C.H.; Kim, M.S. Changes in leaf variegation and coloration of english ivy and polka dot plant under various indoor light intensities. HortTechnology 2012, 22, 49-55. [CrossRef] 
32. Wellburn, A. The spectral determination of chlorophylls a and b, as well as total carotenoids, using various solvent with spectrophotometers of different resolution. J. Plant Physiol. 1994, 144, 307-313. [CrossRef]

33. Valdes, R.; Miralles, J.; Franco, J.A.; Sánchez-Blanco, M.J.; Bañón, S. Using soil bulk electrical conductivity to manage saline irrigation in the production of potted poinsettia. Sci. Hortic. 2014, 170, 1-7. [CrossRef]

34. Li, Q.; Chen, J.; McConnell, D.B.; Henny, R.J. A simple and effective method for quantifying leaf variegation. HortTechnology 2007, 17, 285-288. [CrossRef]

35. Ben Amor, N.; Ben Hamed, K.; Debez, A.; Grignon, C.; Abdelly, C. Physiological and antioxidant responses of the perennial halophyte Crithmum maritimum to salinity. Plant Sci. 2005, 168, 889-899. [CrossRef]

36. Rodriguez, J.L.; Davies, W.J. The effect of temperature and ABA on stomata of Zea mays L. J. Exp. Bot. 1982, 33, 977-987. [CrossRef]

37. Irigoyen, J.J.; Emerich, D.W.; Sánchez-Díaz, M. Water stress induced changes in concentrations of proline and total soluble sugars in nodulated alfalfa (Medicago sativa) plants. Physiol. Plant. 1992, 84, 55-60. [CrossRef]

38. Bradford, M.M. A rapid and sensitive method for the quantitation of microgram quantities of protein utilizing the principle of protein-dye binding. Anal. Biochem. 1976, 72, 248-254. [CrossRef]

39. Hatano, T.; Kagawa, H.; Yasuhara, T.; Okuda, T. Two new flavonoids and other constituents in licorice root their relative astringency and radical scavenging effect. Chem. Pharm. Bull. 1988, 36, 2090-2097. [CrossRef]

40. Osman, H.S.; Salim, B.B. Influence of exogenous application of some phytoprotectants on growth, yield and pod quality of snap bean under $\mathrm{NaCl}$ salinity. Ann. Agric. Sci. 2016, 61, 1-13. [CrossRef]

41. Yildirim, E.; Ekinci, M.; Turan, M.; Dursun, A.; Kul, R.; Parlakova, F. Roles of glycine betaine in mitigating deleterious effect of salt stress on lettuce (Lactuca sativa L.). Arch. Agric. Soil Sci. 2015, 61, 1673-1689. [CrossRef]

42. Cassaniti, C.; Leonardi, C.; Flowers, T.J. The effect of sodium chloride on ornamental shrubs. Sci. Hortic. 2009, 122, 586-593. [CrossRef]

43. García-Caparrós, P.; Lao, M.T. The effects of salt stress on ornamental plants and integrative cultivation practices. Sci. Hortic. 2018, 240, 430-439. [CrossRef]

44. Sobahan, M.A.; Akter, N.; Ohno, M.; Okuma, E.; Hirai, Y.; Mori, I.C.; Nakamura, Y.; Murata, Y. Effects of exogenous proline and glycine betaine on the salt tolerance of rice cultivars. Bio. Biotech. Biochem. 2012, 76, 1568-1570. [CrossRef] [PubMed]

45. Vladimirova, S.V.; McConnell, D.B.; Kane, M.E.; Henley, R.W. Morphological plasticity of Dracaena sanderana 'Ribbon' in response to four light intensities. HortScience 1997, 32, 1049-1052. [CrossRef]

46. Nam, Y.K.; Kwack, H.R.; Kwack, B.H. Different extents of leaf-variegation in Epipremnum aureum as influenced by different light levels. J. Kor. Soc. Hort. Sci. 1997, 38, 537-540.

47. Pennisi, S.; van Iersel, M.W.; Burnett, S.E. Photosynthetic irradiance and nutrition effects on growth of English ivy in subirrigation systems. HortScience 2005, 40, 1740-1745. [CrossRef]

48. Shen, G.W.; Seeley, J.G. The effect of shading and nutrient supply on variegation and nutrient content of variegated cultivars of Peperomia obtusifolia. J. Am. Soc. Hort. Sci. 1983, 108, 429-433.

49. Leyva, R.; Sánchez-Rodríguez, E.; Ríos, J.J.; Rubio-Wilhelmi, M.M.; Romero, L.; Ruiz, J.M.; Blasco, B. Beneficial effects of exogenous iodine in lettuce plants subjected to salinity stress. Plant Sci. 2011, 181, 195-202. [CrossRef]

50. Athar, H.; Zafar, Z.U.; Ashraf, M. Glycinebetaine improved photosynthesis in canola under salt stress: Evaluation of chlorophyll fluorescence parameters as potential indicators. J. Agron. Crop Sci. 2015, 201, 428-442. [CrossRef]

51. Mäkela, P.; Mantila, J.; Hinkkanen, R.; Pehu, E.; Peltnen-Sainio, P. Effect of foliar applications of glycinebetaine on stress tolerance, growth and yield of spring cereals and summer turnip rape in Finland. J. Agron. Crop Sci. 1996, 176, 223-234. [CrossRef]

52. Athar, H.; Ashraf, M.; Wahid, A.; Jamil, A. Inducing salt tolerance in canola (Brassica napus L.) by exogenous application of glycinebetaine and proline: Response at the initial growth stages. Pak. J. Bot. 2009, 41, 1311-1319.

53. Yang, Z.; Yu, J.; Merewitz, E.; Huang, B. Differential effects of abscisic acid and glycine betaine on physiological responses to drought and salinity stress for two perennial grass species. J. Am. Soc. Hortic. Sci. 2012, 137, 96-106. [CrossRef]

54. Rajendran, K.; Tester, M.; Roy, S.J. Quantifying the three main components of salinity tolerance in cereals. Plant Cell Environ. 2009, 32, 237-249. [CrossRef] [PubMed] 
55. Schilling, R.K.; Marschner, P.; Shavrukov, Y.; Berger, B.; Tester, M.; Roy, S.J.; Plett, D.C. Expression of the Arabidopsis vacuolar $\mathrm{H}^{+}$-pyrophosphatase gene ( $\left.A V P 1\right)$ improves the shoot biomass of transgenic barley and increases grain yield in a saline field. Plant Biotechnol. J. 2014, 12, 378-386. [CrossRef] [PubMed]

56. Holmstrom, K.O.; Somersalo, S.; Mandal, A.; Palva, E.T.; Welin, B. Improved tolerance to salinity and low temperature in transgenic tobacco producing glycine betaine. J. Exp. Bot. 2000, 51, 177-185. [CrossRef] [PubMed]

57. Manaf, H.H. Beneficial effects of exogenous selenium, glycine betaine and seaweed extract on salt stressed cowpea plant. Ann. Agric. Sci. 2016, 61, 41-48. [CrossRef]

58. Silveira, J.A.; Carvalho, F.E. Proteomics, photosynthesis and salt resistance in crops: An integrative view. J. Proteom. 2016, 143, 24-35. [CrossRef]

59. Scalia, R.; Oddo, E.; Russo, G.; Saiano, F.; Grisafi, F. Effectiveness of glycinebetaine foliar application in relieving salt stress symptoms in two turf-grasses. Grassland Sci. 2014, 60, 92-97. [CrossRef]

60. Khalifa, G.S.; Abdelrassoul, M.; Hegazi, A.M.; Elsherif, M.H. Attenuation of negative effects of saline stress in two lettuce cultivars by salicylic acid and glycine betaine. Gesunde Pflanz. 2016, 68, 177-189. [CrossRef]

61. Chaum, S.; Kirdmanee, C. Effect of salt stress on proline accumulation, photosynthetic ability and growth characters in two maize cultivars. Pak. J. Bot. 2009, 41, 87-98.

62. Maksimovic, I.; Putnik-Delić, M.; Gani, I.; Marić, J.; Ilin, Ž. Growth, ion composition, and stomatal conductance of peas exposed to salinity. Cent. Eur. J. Biol. 2010, 5, 682-691. [CrossRef]

63. Slama, I.; Abdelly, C.; Bouchereau, A.; Flowers, T.J.; Savouré, A. Diversity, distribution and roles of osmoprotective compounds accumulated in halophytes under abiotic stress. Ann. Bot. 2015, 115, 433-447. [CrossRef] [PubMed]

64. Korkmaz, A.; Şirikçi, R.; Kocaçınar, F.; Değer, Ö.; Demirkırıan, A.R. Alleviation of salt-induced adverse effects in pepper seedlings by seed application of glycinebetaine. Sci. Hortic. 2012, 148, 197-205. [CrossRef]

65. Liang, C.; Zhang, X.Y.; Luo, Y.; Wang, G.P.; Zouand, Q.; Wang, W. Overaccumulation of glycinebetaine alleviates the negative effects of salt stress in wheat. Russ. J. Plant Physiol. 2009, 56, 370-376. [CrossRef]

66. Demiral, T.; Türkan, I. Exogenous glycine betaine affects growth and proline accumulation and retards senescence in two rice cultivars under $\mathrm{NaCl}$ stress. Environ. Exp. Bot. 2006, 56, 72-79. [CrossRef]

67. Mohammed, A.R.; Tarpley, L. Characterization of rice (Oryza sativa L.) physiological responses to $\alpha$-tocopherol, glycine betaine or salicylic acid application. J. Agric. Sci. 2011, 3, 3. [CrossRef] 